\title{
Freiberg's infraction
}

\author{
Hsi-Ting Lin, Andy Li-Jen Liu
}

Department of Orthopedic Surgery, Cathay General Hospital, Taipei, Taiwan

\section{Correspondence to}

Dr Andy Li-Jen Liu, dmd00md05@gmail.com
To cite: Lin H-T, Liu AL-J. BMJ Case Rep Published online: [please include Day Month Year] doi:10.1136/ bcr-2013-010121

\section{DESCRIPTION}

The patient is a 16-year-old girl who visited the clinic and presented with a 3-month history of right foot pain. She described the pain as constant and dull, and exacerbated with walking. No traumatic history was noted. Physical examination revealed evident swelling and tenderness near the second metatarsophalangeal (MTP) joint. Radiograph of the right foot revealed flattening of the second metatarsal head with subchondral sclerosis and fragmentation within the joint (figure 1). In addition, MRI demonstrated hyperintense signals on T2-weighted images (figure 2A,B). Based on clinical and radiological information, Freiberg's infraction was diagnosed and the patient was treated conservatively with rest and activity modification. After 2 months of follow-up, she was walking pain-free.

Freiberg's infraction is a rare disease characterised by osteonecrosis of the metatarsal head primarily affecting the second metatarsal. ${ }^{1}$ With its multifactorial aetiology, the condition predominantly occurs in teenagers with a $5: 1$ female predilection. ${ }^{2}$ Patients often present with pain and swelling around the MTP joint. ${ }^{1}$ The radiographic appearance is typical with flattening of the second metatarsal head, increased sclerosis and loose body formation within the joint. MRI is useful in its diagnosis, as T2-weighted images often show increased signal intensity in the metatarsal head. ${ }^{3}$ Since most cases are self-limited, conservative therapy in the form of rest, crutches or casting may be adequate. Surgery is rarely indicated and is reserved for patients who fail

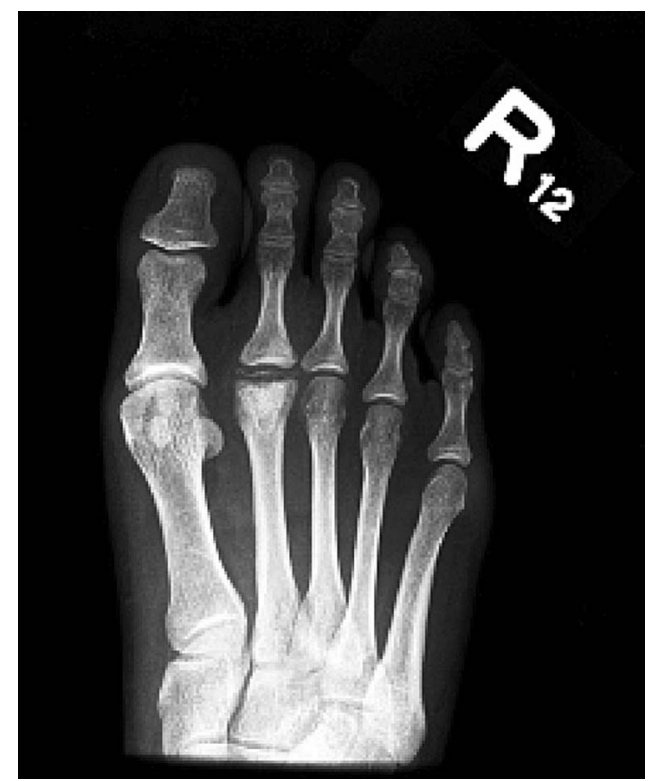

Figure 1 Anteroposterior radiograph of the right foot showing flattening of the second metatarsal head and subchondral sclerosis with fragmentation within the metatarsophalangeal joint.
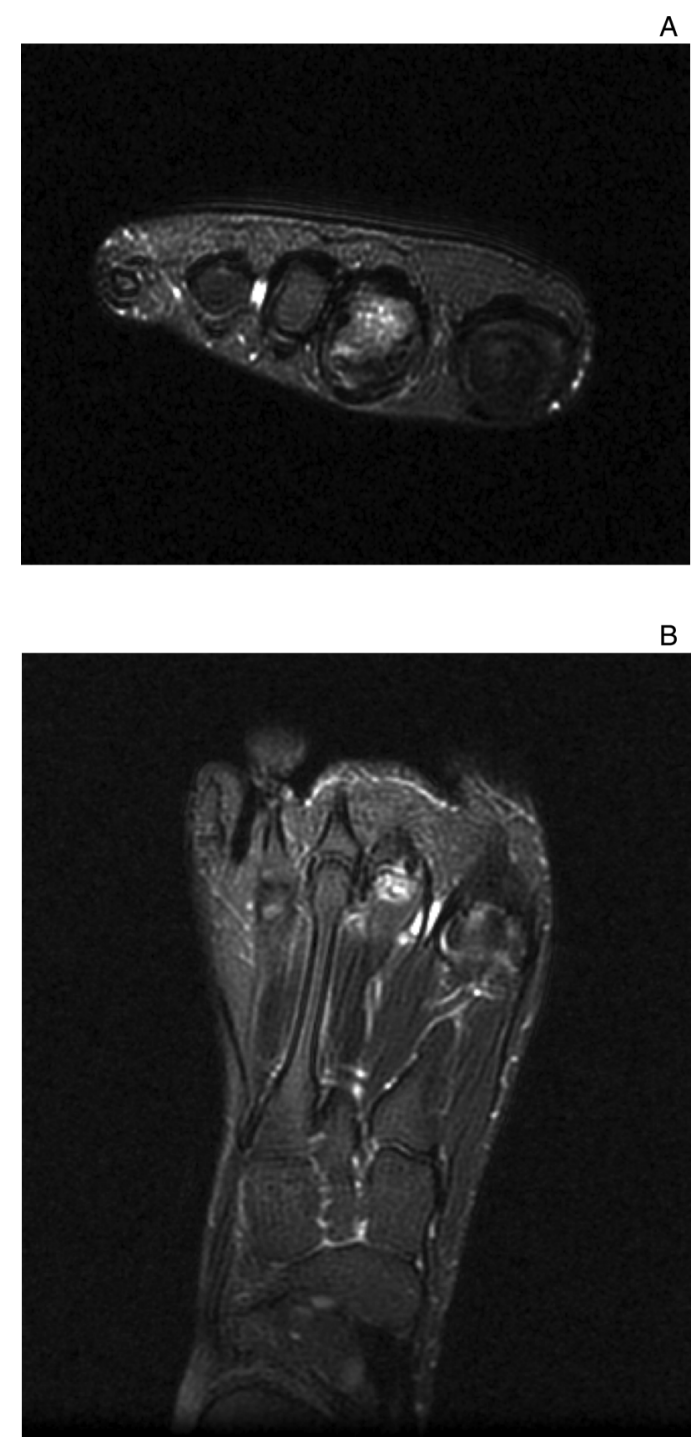

Figure 2 MRI, T2-weighted axial (A) and coronal (B) views of the right foot. Note the increased signal intensity at the second metatarsal head.

conservative management; it can range from metatarsal neck osteotomy and joint debridement to resection of the metatarsal head. ${ }^{1-3}$

\section{Learning points}

- Freiberg's infraction is a rare disease characterised by osteonecrosis of the second metatarsal head; it is most commonly seen in teenage girls.

- Radiographically, the second metatarsal head has a flattened appearance with areas of increased sclerosis and fragmentation.

- Initial management should be conservative with surgery reserved for patients unresponsive to non-surgical treatment. 
Contributors $\mathrm{H}-\mathrm{TL}$ is the primary orthopaedic surgeon who cared for the patient, is responsible for the conception and design of this paper, along with final approval of the paper before submission. AL-JL is the orthopaedic surgeon who cared for the patient, acquired and interpreted the data, and drafted and edited the article for submission.

Competing interests None.

Patient consent Obtained.

Provenance and peer review Not commissioned; externally peer reviewed.

\section{REFERENCES}

1 Ahmad J, Raikin SM. Osteonecrosis of the second metatarsal head, navicular and talus. Curr Opin Orthop 2006;17:103-10.

2 Carmont MR, Rees RJ, Blundell CM. Current concepts review: Freiberg's disease. Foot Ankle Int 2009:30:167-76.

3 Cerrato RA. Freiberg's disease. Foot Ankle Clin N Am 2011;16:647-58.

Copyright 2013 BMJ Publishing Group. All rights reserved. For permission to reuse any of this content visit http://group.bmj.com/group/rights-licensing/permissions.

BMJ Case Report Fellows may re-use this article for personal use and teaching without any further permission.

Become a Fellow of BMJ Case Reports today and you can:

- Submit as many cases as you like

- Enjoy fast sympathetic peer review and rapid publication of accepted articles

- Access all the published articles

- Re-use any of the published material for personal use and teaching without further permission

For information on Institutional Fellowships contact consortiasales@bmjgroup.com

Visit casereports.bmj.com for more articles like this and to become a Fellow 